\title{
IMPLEMENTASI KEBIJAKAN ALOKASI DANA DESA DI DESA MARIA KECAMATAN WAWO KABUPATEN BIMA
}

\section{IMPLEMENTATION OF VILLAGE FUND ALLOCATION POLICY IN MARIA VILLAGE, WAWO DISTRICT, BIMA REGENCY}

\section{Haerun Yasin \\ Sekolah Tinggi Ilmu Social Dan Ilmu Politik (STISIP) Mbojo-Bima email: \\ haerunyasin@gmail.com}

\section{Sri Wahyuli}

Sekolah Tinggi Ilmu Social Dan Ilmu Politik (STISIP) Mbojo-Bima email:

sriwahyuli523@gmail.com

JGPI

p-ISSN: 2774-907X e-ISSN: 2775-0140 Vol. 1, No. 2, pp. 129139

Oktober 2021

Unit Publikasi Ilmiah Intelektual Madani Indonesia
Abstrak: Semangat membangun tata pengelolaan Dana Desa baik yang bersumber dari Pemerintah Pusat maupun Pemerintah Daerah, sehingga Desa-Desa di Indonesia khususnya Desa Maria yang ada di kecamatan Wawo dapat berkembang secara menyeluruh dan tingkat perkembangan masing-masing. Bantuan Langsung Alokasi Dana Desa yang selanjutnya disebut ADD adalah dana bantuan langsung yang dialokasikan kepada Pemerintah Desa. Tujuan penelitian ini adalah untuk mengetahui penyerapan alokasi Anggaran Dana Desa (ADD) di Desa Maria Kecamatan Wawo Kabupaten Bima. Adapun Metode peneilitian ini yaitu kuantitatif, Data yang terkumpul kemudian di analisa dengan teknik analisis data dengan menggunakan SPSS 16.0 for windows. Kemudian adapun teknik pengumpulan data yaitu observasi, quisioner, dan studi kepustakaan. Sehingga dapat disimpulkan bahwa jawaban responden yang mengatakan sangat baik $59,78 \%$, kemudian responden yang menjawab baik $29,12 \%$, dan responden yang menjawab cukup baik $7,10 \%$, serta responden yang menjawab kurang baik 4\%. Ini mengindikasikan bahwa Pemerintah Desa Maria telah mengalokasikan angggaran dana desa (ADD) dengan baik walaupun terdapat $4 \%$ yang menjawab kurang baik, hal ini penting untuk dilakukan restrukturisasi alokasi sesuai tepat sasaran, agar angka 4\% dapat diminimalisir dengan baik Pemerintah Desa Maria bersama BPD.

Kata kunci : Kebijakan, Alokasi, Dana Desa

Abstract: The spirit of building the management of Village Funds both sourced from the Central Government and Regional Governments, so that villages in Indonesia, especially Maria Village in Wawo sub-district, can develop as a whole and at their respective levels of development. Village Fund Allocation Direct Assistance, hereinafter referred to as $A D D$, is a direct assistance fund allocated to the Village Government. The purpose of this study was to determine the absorption of the Village Fund Budget (ADD) in Maria Village, Wawo District, Bima Regency. The research method is quantitative. The collected data is then analyzed with data analysis techniques using SPSS 16.0 for windows. Then the data collection techniques are observation, questionnaire, and literature study. So it can be concluded that the answers of respondents who said very well 59.78\%, then respondents who answered well $29.12 \%$, and respondents who answered quite well $7.10 \%$, and respondents who answered less well 4\%. This indicates that the Maria Village Government has allocated the village fund budget (ADD) well, although there are $4 \%$ who answered less well, it is important to restructure the allocation according to the target, so that the 4\% figure can be minimized properly.

Keywords: Policy, Allocation, Village Fund 


\section{PENDAHULUAN}

Berdasarkan UU nomor 6 tahun 2014 tentang desa pasal 1 ayat 1 bahwa Desa adalah desa dan desa adat stsu ysng disebut dengan nama lain, selanjutnya disebut desa adalah kesatuan masyarakat hukum yang memiliki batas wilayah yang berwenang untuk mengatur dan mengurus urusan pemerintahan, kepentingan masyarakat setempat berdasarkan prakarsa masyarakat, asal usul, dan/atau hak tradisional yang diakui dan dihormati dalam sistem pemerintahan negara kesatuan repiblik indonesia. Pengelolaan serta Pembangunan Desa yang dilaksanakan tidak hanya menjadi tanggung jawab pemerintah, melainkan harus dengan dukungan serta partisipasi aktif masyarakat, karena pengelolaan Dana Desa dalam pembangunan pada dasarnya adalah suatu pembangunan dari masyarakat, oleh masyarakat dan untuk masyarakat Desa itu sendiri. Dinamika kebijakan publik menjadi potret yang mewarnai perjalanan pelayanan yang diberikan kepada penyelenggara kepada seluruh elemen masyarakat, pelayanan prima menjadi amunisi yang perlu diorbitkan sebagai garda terdepan yang langsung beriteraksi antara pemerintah sebagai penyelenggara dengan masyarakat sebagai penerima atau pemanfaat pelayanan sebagai representatif eksistensi negara terhadap rakyat (Taufik irfadat, dkk).

Menurut zakaria dalam wahjudin sumpeno (2011:3) menyatakan bahwa desa adalah sekumpulan manusia yang hidup bersama atau suatu wilayah, yang memiliki organisasi pemerintahan dengan serangkaian peraturan-peraturan yang ditetapkan sendiri, serta berada dibawah pimpinan desa yang dipilih dan ditetapkan sendiri. Atas dasar itu diperlukan adanya upaya Pemerintah untuk memberikan kesadaran kepada masyarakat agar partisipasinya dalam pembangunan serta pengelolaan Dana Desa yang dilakukan oleh Pemerintah untuk kepentingan masyarakat secara keseluruhan. Tugas menyadarkan masyarakat merupakan tanggunga jawab Kepala Desa sebagai penyelenggara pengelolaan Dana Desa dan penaggung jawab utama di bidang Pemerintahan, pembangunan, pengelolaanya, kemasyarakatan, dan ketertiban.

Alokasi anggaran dana desa (ADD) adalah dana yang bersumber dari anggaran dan pendapatan belanja Negara yang diperuntukkan bagi desa yang ditransfer melalui anggara pendapatan belanja daerah kabupaten/kota dan digunakan untuk membiayai penyelenggaraan pemerintahan, pelaksanaan pembangunan, pembinaan kemasyarakatan, dan pemberdayaan masyarakat (Deti Kumalasari, dkk). Disamping itu juga mengemban tugas membangun mental masyarakat baik dalam bentuk menumbuh 
kembangkan semangat membangun yang di jiwai oleh asas usaha bersama dan kekeluargaan dalam kaitanya dengan tata pengelolaan Dana Desa baik yang bersumber dari Pemerintah Pusat maupun Pemerintah Daerah, sehingga Desa-Desa di Indonesia khususnya Desa Maria yang ada di kecamatan Wawo dapat berkembang secara menyeluruh dan terpadu menurut typologi dan tingkat perkembangan masing-masing. Penyelenggaraan serta tata pengelolaan Dana Desa baik yang bersumber dari Pusat maupun Pemerintah Daerah serta swadaya masyarakat dilaksanakan terutama melalui peningkatan prakarsa dan swadaya masyarakat Desa. Semangat itu secara tidak langsung telah memberi pemahaman dan optimisme terhadap masyarakat Desa sebagai komunitas yang hidup dengan segala potensinya, yang mampu membangun dan menghidupi dirinya sendiri. Segenap upaya dalam pengololaan Dana Desa baik yang bersumber dari pemerintah pusat maupun daerah serta swadaya masyarakat yang ditujukan terhadap pembangunan desa justru hendaknya dalam rangka membamgkitkan prakarsa dan swadaya masyarakat pedesaan, sehingga mereka mampu mengefektifkan potensi yang ada dengan lebih cepat dan lebih besar lagi. Keterkaitannya dengan penyelenggaraan tata pengelolaan Dana Desa, Pemerintah Desa Maria selaku penyelenggara Pemerintah dan pelaksanaan dalam pembangunan Desa, di kenal 2 (dua) kelembagaan yang terdepan selaku mitra kerja Pemerintah Desa, yaitu Badan Permusyawaratan Desa (BPD) dan Lembaga Pemberdayaan Masyarakat Desa (LPMD) yang memiliki peranan cukup besar dalam hal perencanaan dan tata pengelolaan Dana Desa baik yang bersumber dari Pemerintah Pusat maupun Pemerintah Daerah serta Swadaya masyarakat.

Dewasa ini pemerintah Indonesia terus mengupayakan peningkatan pelaksanaan pembangunan nasional agar laju pembangunan daerah serta laju pembangunan desa dan kota semakin seimbang dan serasi. Masalah pokok pembangunan seperti ketimpangan pembangunan antara desa dan kota di Indonesia. (Candra kusuma p. dkk) .Kepala Desa sebagai pimpinan di Desa dalam pelaksanaan tugasnya selaku penyelenggara serta penaggung jawab utama di bidang pemerintahan, pengelolaan, pembangunan, kemasyarakatan dan urusan pemerintahan umum, termasuk pembinaan dan ketertiban menurut yang di atur dalam Undang-Undang No. 6 Tahun 2014 Tentang Desa, maka dalam menjalankan tugas dan kewajibanya itu seperti telah di uraikan, sebaga mitranya yaitu Badan Permuswaratan Desa yang beranggotakan unsur-unsur tokoh dari semua dusun dalam Wilayah Desa yang bersangkutan. Robert Eyestone 
mengatakan bahwa secara luas kebijakan public dapat didefinisikan "sebagai hubungan suatu unit pemerintah dengan lingkungannya". Sedangkan menurut Thomas R. dye mengatakan bahwa kebijakan public adalah "apa yang dipilih oleh pemerintah untuk dilakukan dan tidak dlakukan". Namun dala buku yang berjudul what government do, why they do it, what differens it makes tahun 1976, dye dengan tegas mengatakan bahwa kebijakan public adalah "studi tentang apa yang dilakukan oleh pemerintah, mengapa pemerintah mengambil tindakan tersebut, dan apa akibat dari tindakan tersebut".

Bantuan Langsung Alokasi Dana Desa yang selanjutnya disebut ADD adalah dana bantuan langsung yang dialokasikan kepada Pemerintah Desa digunakan untuk meningkatkan sarana pelayanan masyarakat, kelembagaan dan prasarana Desa yang diperlukan serta diprioritaskan oleh masyarakat, yang pemanfaatan dan administrasi pengelolaannya dilakukan dan dipertanggung jawabkan oleh Kepala Desa. Bantuan Langsung Alokasi Dana Desa (ADD) dimaksudkan sebagai bantuan stimulant atau dana perangsang untuk mendorong dalam membiayai program Pemerintah Desa yang ditunjang dengan partisipasi swadaya gotong royong masyarakat dalam melaksanakan kegiatan pemerintahan dan pemberdayaan. Edward III dalam Subarsono $(2005 ; 90)$ memberikan pandangan bahwa implementasi kebijakan dipengaruhi oleh empat variable, yakni : (1) komunikasi, (2) sumberdaya, (3) disposisi (sikap), (4) stuktur birokrasi. dan keempat variabel tersebut saling berhubungan satu sama lain.

\section{METODE}

Metode peneilitian ini adalah kuantitatif, Data yang terkumpul kemudian di analisa dengan teknik analisis data menggunakan SPSS 16.0 for windows. Untuk menyajikan data yang sistematis berdasarkan quisioner yang diberikan kepada responden dan diperkuat oleh observasi langsung tentang Implementasi Kebijakan Dana Desa Di Desa Maria Kecamatan Wawo Kabupaten Bima.

\section{HASIL DAN DISKUSI}

Secara umum pelaksanaan Alokasi Dana Desa (ADD) telah berjalan dengan baik. Namun demikian pelaksanaan kebijakan penggunaan Alokasi Dana Desa di Desa Maria Kecamatan wawo Kabupaten Bima masih terdapat kendala. Hal tersebut dapat diketahui melalui berbagai fenomena yang ditemukan selama melaksanakan penelitian. Adapun fenomena yang diteliti dalam pelaksanaan alokasi dana desa sebagai berikut: 


\section{Proses Penyusunan Rencana Kegiatan Pelaksanaan Kebijakan Penggunaan Alokasi Dana Desa di Desa Maria Kecamatan Wawo Kabupaten Bima}

Tabel 1. Proses Penyusunan Rencana Kegiatan Pelaksanaan Kebijakan Penggunaan Alokasi Dana Desa di Desa Maria Kecamatan Wawo Kabupaten Bima

\begin{tabular}{|c|l|c|c|}
\hline No & \multicolumn{1}{|c|}{ Kriteria penilaian } & Frekuensi & Prosentase (\%) \\
\hline 1 & Sangat berhasil & 16 & $32,05 \%$ \\
2 & Berhasil & 33 & $65,95 \%$ \\
3 & Kurang berhasil & 1 & $2 \%$ \\
4 & Tidak berhasil & 0 & $0 \%$ \\
\hline & Jumlah & 50 & $100 \%$ \\
\hline
\end{tabular}

Sumber : Data Kuesioner, tahun 2021

Mengacu pada data di atas, maka dapat digambarkan bahwa penyusunan rencana kegiatan kebijakan penggunaan alokasi dana desa di Desa Maria Kecamatan Wawo Kabupaten Bima, responden menilai sangat berhasil 32,05\%, kemudian responden menilai berhasil 65,95\%, kemudian responden menjawab kurang berhasil 2\%, dan responden menjawab tidak berhasil 0\%. Berarti penyusunan rencana kegiatan kebijakan penggunaan alokasi dana desa di Desa Maria Kecamatan Wawo Kabupaten Bima dikategorikan berhasil. Artinya bahwa penyusun rencana kegiatan tersebut berjalan dengan berhasil.

Tabel 2. Tingkat Kepuasan Masyarakat Terhadap Perencanaan Kegiatan Desa

\begin{tabular}{|c|l|c|c|}
\hline No & Kriteria penilaian & Frekuensi & Prosentase (\%) \\
\hline 1 & Sangat baik & 10 & $35 \%$ \\
2 & Baik & 15 & $49,80 \%$ \\
3 & Cukup baik & 5 & $15,20 \%$ \\
4 & Kurang baik & 0 & $0 \%$ \\
\hline & Jumlah & 30 & $100 \%$ \\
\hline
\end{tabular}

Sumber: Kantor Desa Maria, Tahun 2020

Berdasarkan data table di atas bahwa jawaban masyarakat pada perencanaan kegiatan pada Desa Maria yaitu, responden yang menjawab sangat baik 35\%, kemudian responden yang menjawab baik 49,80\%, kemudian responde yang menjawab cukup baik15,20\%, dan responden yang menjawab kurang baik 0\%. Ini mengindikasikan bahwa tingkat kepuasan masyarakat baik. 


\section{Realisasi Pelaksanaan Kebijakan Pengguanaan Alokasi Dana Desa}

Tabel 3. Realisasi Pelaksanaan Kebijakan Pengguanaan Alokasi Dana Desa di Desa Maria Kecamatan Wawo Kabupaten Bima (pembangunan kantor desa)

\begin{tabular}{|l|l|c|c|}
\hline No & \multicolumn{1}{|c|}{ Kriteria penilaian } & Frekuensi & Prosentase (\%) \\
\hline 1 & Sangat Berhasil & 11 & $22 \%$ \\
2 & berhasil & 30 & $60 \%$ \\
3 & Kurang berhasil & 9 & $18 \%$ \\
4 & Tidak berhasil & 0 & $0 \%$ \\
\hline & Jumlah & 50 & $100 \%$ \\
\hline
\end{tabular}

Sumber : Data Kuesioner, tahun 2021

Mengacu pada data di atas, maka dapat digambarkan bahwa realisasi penggunaan alokasi dana desa pada pos pembangunan kantor Desa Maria Kecamatan Wawo Kabupaten Bima, responden menjawab sangat berhasil 22\%. Kemudian responden menjawab berhasil 60\%, dan responden menjawab kurang berhasil 18\%, serta responden yang menjawab tidak berhasil adalah $0 \%$. Berarti realisasi anggaran realisasi anggaran alokasi dana desa pada pos pembangunan kantor Desa Maria Kecamatan Wawo Kabupaten Bima dikategorikan berhasil. Artinya bahwa realisasi anggaran alokasi dana desa tersebut berhasil.

Tabel 4 Tingkat Kepuasan Masyarakat Pada Alokasi Anggaran Dana Desa (ADD)

\begin{tabular}{|c|l|c|c|}
\hline No & \multicolumn{1}{|c|}{ Kriteria penilaian } & Frekuensi & Prosentase (\%) \\
\hline 1 & Sangat baik & 9 & $30 \%$ \\
2 & Baik & 19 & $59,80 \%$ \\
3 & Cukup baik & 2 & $10,20 \%$ \\
4 & Kurang baik & 0 & $0 \%$ \\
\hline & Jumlah & 30 & $100 \%$ \\
\hline
\end{tabular}

Sumber : Kantor Desa Maria, Tahun 2020

Berdasarkan data di atas bahwa jawaban masyarakat pada tingkat kepuasan masyarakat di Desa Maria terhadap alokasi Anggaran Dana Desa yaitu, adapun responden yang menjawab sangat baik 30\%, kemudian responden yang menjawab baik $59,80 \%$, kemudian responde yang menjawab cukup baik 10,20\% dan responden yang menjawab kurang baik 0\%. Ini mengindikasikan bahwa tingkat kepuasan masyarakat baik. 


\section{Realiasasi Pengguanaan Alokasi Dana Desa Pada Pos Tabel 5. Pengguanaan Alokasi Dana Desa Pada Pos Ekonomi Ekonomi (Bantuan Modal Usaha)}

\begin{tabular}{|c|l|c|c|}
\hline No & \multicolumn{1}{|c|}{ Kriteria penilaian } & Frekuensi & Prosentase (\%) \\
\hline 1 & Sangat berhasil & 7 & $16 \%$ \\
2 & Berhasil & 24 & $48 \%$ \\
3 & Kurang berhasil & 16 & $32 \%$ \\
4 & Tidak berhasil & 3 & $4 \%$ \\
\hline & Jumlah & 50 & $100 \%$ \\
\hline
\end{tabular}

Sumber : Data Kuesioner, tahun 2021

Mengacu pada data di atas, maka dapat digambarkan bahwa realisasi penggunaan alokasi dana desa pada pos ekonomi responden menilai sangat berhasil 20\%. Kemudian responden menjawab berhasil 48\%, dan responden yang menjawab kurang berhasil $32 \%$, dan responden yang menajwab tidak berhasil $4 \%$. Berarti realisasi penggunaan realisasi penggunaan alokasi dana desa pada pos ekonomi dikategorikan berhasil namun terdapat jawaban yang mencengangkan bahwa lebih besar persentase jawaban kurang berhasil dan tidak berhasil dibanding sangat berhasil. Artinya bahwa realisasi penggunaan alokasi dana desa tersebut kurangtepat waktu, tidak tepat sasaran, dan masih belum merata.

Table 6 Tingkat Kepuasan Pelaku Usaha Dalam Memperoleh Bantuan Modal

\begin{tabular}{|c|l|c|c|}
\hline No & \multicolumn{1}{|c|}{ Kriteria penilaian } & Frekuensi & Prosentase (\%) \\
\hline 1 & Sangat baik & 4 & $9,50 \%$ \\
2 & Baik & 12 & $48,30 \%$ \\
3 & Cukup baik & 9 & $30,20 \%$ \\
4 & Kurang baik & 5 & $12 \%$ \\
\hline & Jumlah & 30 & $100 \%$ \\
\hline
\end{tabular}

Sumber : kantor desa maria, tahun 2020

Berdasarkan data di atas bahwa jawaban masyarakat pada tingkat kepuasan masyarakat di Desa Maria terhadap bantuan modal usaha dari Pemerintah Desa Maria yaitu, adapun responden yang menjawab sangat baik 9,50\%, kemudian responden yang menjawab baik $48,80 \%$, kemudian responde yang menjawab cukup baik $30,20 \%$ dan responden yang menjawab kurang baik $12 \%$. 


\section{Realisasi Penggunaan Alokasi Dana Desa Pada Pos \\ Tabel 7. Realisasi Penggunaan Alokasi Dana Desa Pada Pos Keagamaan (Seleksi} Tilawatil Qur'an tingkat Desa)

\begin{tabular}{|c|l|c|c|}
\hline No & \multicolumn{1}{|c|}{ Kriteria tanggapan } & Frekuensi & Prosentase (\%) \\
\hline 1 & Sangat berhasil & 8 & $16 \%$ \\
2 & Berhasil & 41 & $80 \%$ \\
3 & Kurang Berhasil & 2 & $4 \%$ \\
4 & Tidak berhasil & 1 & $2 \%$ \\
\hline & Jumlah & 50 & $100 \%$ \\
\hline
\end{tabular}

Sumber : Data Kuesioner, tahun 2021

Mengacu pada data di atas, maka dapat digambarkan bahwa realisasi penggunaan alokasi dana desa pada pos keagamaan (seleksi tilawatil Qur'an tingkat desa) responden menjawab sangat berhasil 16\%, kemudian responden yang menjawab berhasil $80 \%$ dan responden 4\%, serta responden yang menjawab tidak berhasil $2 \%$. Berarti realisasi anggaran realisasi anggaran alokasi dana desa pada pos keagamaan (seleksi tilawatil Qur'an tingkat desa) dikategorikan berhasil meskipun terdaapt jawaban yang kurang berhasil dan tidak berhasil. Artinya bahwa realisasi anggaran alokasi dana desa tersebut cukup baik.

Tabel 8. Tingkat Kepuasan Masyarakat Terhadap Alokasi Anggaran Pada Bidang Keagamaan

\begin{tabular}{|c|l|c|c|}
\hline No & \multicolumn{1}{|c|}{ Kriteria penilaian } & Frekuensi & Prosentase (\%) \\
\hline 1 & Sangat baik & 5 & $14,50 \%$ \\
2 & Baik & 12 & $48,30 \%$ \\
3 & Cukup baik & 10 & $30,20 \%$ \\
4 & Kurang baik & 3 & $7 \%$ \\
\hline & Jumlah & 30 & $100 \%$ \\
\hline
\end{tabular}

Sumber Data : Kantor Desa Maria, Tahun 2020

Berdasarkan data di atas bahwa jawaban masyarakat pada tingkat kepuasan masyarakat di Desa Maria terhadap alokasi anggara pada bidang keagamaan dari Pemerintah Desa Maria yaitu, adapun responden yang menjawab sangat baik 14,50\%, kemudian responden yang menjawab baik 48,80\%, kemudian responden yang menjawab cukup baik 30,20\% dan responden yang menjawab kurang baik 7\%. 


\section{Realisasi Penggunaan Alokasi Dana Desa pada POS Olahraga \\ Tabel 9. Realisasi Penggunaan Alokasi Dana Desa pada Pos Olahraga (kegiatan sepak bola mini)}

\begin{tabular}{|c|l|c|c|}
\hline No & Kriteria penilaian & Frekuensi & Prosentase (\%) \\
\hline 1 & Sangat berhasil & 10 & $20 \%$ \\
2 & Berhasil & 31 & $62 \%$ \\
3 & Kurang berhasil & 9 & $18 \%$ \\
4 & Tidak berhasil & 0 & $0 \%$ \\
\hline & Jumlah & 50 & $100 \%$ \\
\hline
\end{tabular}

Sumber : Data Kuesioner, tahun 2021

Mengacu pada data di atas, maka dapat digambarkan bahwa realisasi penggunaan alokasi dana desa pada pos kegiatan olah raga, responden menilai sangat berhasil $20 \%$, kemudian responden yang menjawab berhasil 62\%, kemudian responden yang menjawab kurang berhasil 18\%. Dan responden yang menjawab tidak berhasil $0 \%$. Berarti realisasi penggunaan realisasi penggunaan alokasi dana desa pada pos kegiatan olahraga dapat dikatakan berhasil.

Table 10. Tingkat Kepuasan Masyarakat Alomkasi Anggaran Pada Bidang Oleh Raga

\begin{tabular}{|c|l|c|c|}
\hline No & Kriteria penilaian & Frekuensi & Prosentase (\%) \\
\hline 1 & Sangat baik & 8 & $21,50 \%$ \\
2 & Baik & 14 & $56,30 \%$ \\
3 & Cukup baik & 7 & $20,20 \%$ \\
4 & Kurang baik & 1 & $2 \%$ \\
\hline & Jumlah & 30 & $100 \%$ \\
\hline
\end{tabular}

Sumber Data: Kantor Desa Maria, Tahun 2020

Berdasarkan data di atas bahwa jawaban masyarakat pada tingkat kepuasan masyarakat di Desa Maria terhadap alokasi anggara pada bidang olah raga dari Pemerintah Desa Maria yaitu, adapun responden yang menjawab sangat baik 21,50\%, kemudian responden yang menjawab baik 56,30\%, kemudian responden yang menjawab cukup baik 20,20\% dan responden yang menjawab kurang baik $2 \%$. 


\section{Realisasi Penggunaan Alokasi Dana Desa Pada Pos Pendidikan}

Tabel 11. Realisasi Penggunaan Alokasi Dana Desa Pada Pos Pendidikan (bantuan pakaian seragam anak SD sebanyak 25 orang)

\begin{tabular}{|c|l|c|c|}
\hline No & \multicolumn{1}{|c|}{ Kriteria penilaian } & Frekuensi & Prosentase (\%) \\
\hline 1 & Sangat berhasil & 10 & $20 \%$ \\
2 & Berhasil & 27 & $54 \%$ \\
3 & Kurang berhasil & 13 & $26 \%$ \\
4 & Tidak berhasil & 0 & 0 \\
\hline & Jumlah & 50 & $100 \%$ \\
\hline
\end{tabular}

Sumber : Data quesioner, tahun 2021

Mengacu pada data diatas, maka dapat digambarkan bahwa realisasi penggunaan alokasi dana desa pada pos pendidikan (bantuan pakaian seragam anak SD sebanyak 25 orang) responden menilai sangat berhasil 20\%, responden menjawab berhasil 54\%, responden yang menjawab kurang berhasil 26\%, dan responden menjawab tidak berhasil 0\%. Berarti realisasi penggunaan realisasi penggunaan alokasi dana desa pada pos pendidikan dikategorikan berhasil meski terdapat angka kurang berhasil lebih besar dari pada sangat berhasil.

Tabel 12. Tingkat Kepuasan Masyarakat Terhadap Bantuan Pendidikan Bagi Masarakat Kurang Mampu (Seragam Sekolah)

\begin{tabular}{|c|l|c|c|}
\hline No & Kriteria penilaian & Frekuensi & Prosentase (\%) \\
\hline 1 & Sangat baik & 10 & $22,60 \%$ \\
2 & Baik & 14 & $58,30 \%$ \\
3 & Cukup baik & 6 & $19,10 \%$ \\
4 & Kurang baik & 0 & $0 \%$ \\
\hline & Jumlah & 30 & $100 \%$ \\
\hline
\end{tabular}

Sumber Data: Kantor Desa Maria, Tahun 2020

Berdasarkan data diatas bahwa jawaban masyarakat pada tingkat kepuasan masyarakat di Desa Maria terhadap alokasi anggaran pada bidang bantuan pendidikan (seragam sekolah) dari Pemerintah Desa Maria yaitu, adapun responden yang menjawab sangat baik 22,60\%, kemudian responden yang menjawab baik 58,30\%, kemudian responden yang menjawab cukup baik 19,10\% dan responden yang menjawab kurang baik $0 \%$. 


\section{KESIMPULAN}

Berdasarkan data diatas bahwa alokasi Anggaran Dana Desa (ADD) di Desa Maria Kecamatan Wawo Kabupaten Bima, adapun akumulasi dari jawaban responden yang mengatakan sangat baik 59,78\%, kemudian responden yang menjawab baik 29,12\%, dan responden yang menjawab cukup baik $7,10 \%$, serta responden yang menjawab kurang baik 4\%. Ini mengindikasikan bahwa pemeirntah desa maria telah mengalokasikan angggaran dana desa (ADD) dengan baik walaupun terdapat 4\% yang menjawab kurang baik, hal ini penting untuk dilakukan restrukturisasi alokasi sesuai tepat sasaran, agar angka 4\% dapat diminimalisir dengan baik Pemerintah Desa Maria bersama BPD.

\section{REFERENSI}

Taufik irfadat, nurlaila. Dimensi Pelayanan Publik : Potret Ironi Fasilitas Bagi Penyandang Disabilitas Pada Kantor Camat Sape Kabupaten Bima. Jurnal Tata Sejuta Vol.7 No.1 Maret 2021. P-ISSN 2442-9023, EISSN 2615-0670. Jurnal Tata Sejuta STIA MATARAM

Chandra Kusuma Putra, Ratih Nur Pratiwi, Suwondo. 2013. PENGELOLAAN ALOKASI DANA DESA DALAM PEMBERDAYAAN MASYARAKAT DESA (Studi pada Desa Wonorejo Kecamatan Singosari Kabupaten Malang). Jurnal Administrasi Publik (JAP), Vol. 1, No. 6. Hal. 1203-1212 ISSN: 2503-3867jurnal administrasi public

Deti Kumalasari, Ikhsan Budi Riharjo. 2016. TRANSPARANSI DAN AKUNTABILITAS PEMERINTAH DESA DALAM PENGELOLAAN ALOKASI DANA DESA Jurnal Ilmu dan Riset Akuntansi : Volume 5, Nomor 11, November 2016 ISSN : 2460-0585

Robert eyestone, 1971. The tread of policy: a study in policy leadership, Indianapolis: bobbs merril, hlm 18.

dye Thomas R, 1975. Understanding public policy, second edition., Englewood cliff, N. J: prentice hall, hlm. 1

Subarsono, 2005. Analisis Kebijakan Publik, Pustaka Pelajar, Yogyakarta.

Wahjudin, Sumpeno (2011) Perencanaan Desa Terpadu. Banda Aceh,Reinforcement Action and Development.

Undang-Undang No.6 Tahun 2014 Tentang Desa

Kantor desa maria, kecamatan wawo kabupaten bima. 